\title{
Educating innovative and critical thinking managers ${ }^{1}$
}

Paloma Martínez-Hague

Pontificia Universidad Católica del Perú

pmartinezh@pucp.pe

El pensamiento crítico ha sido reconocido como una competencia para la vida y un componente básico de la creatividad y de la innovación. Asimismo, es considerado como una experiencia profesional clave para las organizaciones de todo el mundo. El objetivo de este trabajo es proponer diferentes maneras de enseñar el pensamiento crítico a los futuros administradores para que estén preparados para resolver de manera innovadora las situaciones desafiantes en las organizaciones, aplicando dicho tipo de pensamiento. Esto se logra compartiendo los resultados de la investigación y las herramientas para la educación gerencial.

Palabras clave: pensamiento crítico, educación en gestión, enseñanza, innovación, aprendizaje

Critical thinking is recognized as a competency for life, as a basic component of creativity and innovation; and as a key professional expertise for organizations worldwide. The aim of this paper is to propose different ways of teaching critical thinking to future managers in order to prepare them for challenging organizational situations that must be confronted in an innovative and critical way. This is achieved by sharing research results and tools for management education.

Keywords: critical thinking, management education, teaching, innovation, learning

1. Este artículo está basado en la ponencia presentada, como parte de la sección Call for Papers, durante el I Congreso Internacional de Ciencias de la Gestión: Gestión de la Innovación e Innovación en la Gestión, desarrollado del 29 de setiembre al 2 de octubre de 2015 en la Pontificia Universidad Católica del Perú por el Departamento Académico de Ciencias de la Gestión y la Facultad de Gestión y Alta Dirección. 


\section{Introduction}

The aim of this paper is to propose different ways of teaching critical thinking to future managers and prepare them to face challenging organizational situations by applying innovative reasoning and critical thinking skills. This is achieved by sharing research results and tools for management education.

The paper explores the importance of developing critical thinking skills to transform undergraduate students into critical thinkers; the focus is on management education. First, this article seeks to develop a working definition for the concept of critical thinking based on complementary perspectives. Then, the importance of working on developing critical thinking skills in undergraduate business schools is presented; and some criticism to the current state of the issue is highlighted. The paper recognizes there are central elements for an adequate teaching of critical thinking such as: correct teaching design and methodology, and activities for students to participate in, situations and tasks where they apply critical thinking; all of these within a motivating learning environment that fosters, seeks and evaluates critical thinking.

The methodological framework is provided by exploring concepts like critical pedagogy, active learning and learning communities. Complementarily, the paper presents a number of different experiences from academic research to develop critical thinking in undergraduate management students. These experiences are initiatives, activities and exercises that management teachers can implement to develop critical thinking in students; the focus is on actions that can be incorporated immediately into courses and extracurricular activities. Finally, resources available for students and teachers are commented.

\section{Importance of critical thinking in management education}

Reynolds stated:

The function of management education should not be to help managers fit unquestioningly into the roles traditionally expected of them but to assist them in engaging with the social and moral issues inherent within existing management practice and to become more conscious of the ideological forces which constrain their actions (1999b, p. 182).

Reynolds (1997, 1999a, 1999b) recognized the importance of teaching critical thinking to management students in order to prepare future managers to think and reflect upon their roles and responsibilities towards people and societies; as well as the purpose and moral, economic, even ecological consequences of their actions. This indicates preparing future managers as critical thinkers will not only influence the competitive advantage of the firms they lead but also demonstrates their major role in society.

\section{What is critical thinking?}

Bailin, Case, Coombs and Daniels (1999b) indicated an "adequate conception of critical thinking must construe it as involving both responsible assessment of reasons and 
arguments, and responsible deliberation» (1999b, p. 289). Paul and Elder proposed the following definition, "critical thinking is the art of analysing and evaluating thinking with a view to improving it» (2001, p. 4). The authors also recognized some characteristics of critical thinking such as being "self-directed, self-disciplined, self-monitored and self-corrective thinking» (2001, p. 4). Lipman stated critical thinking is "skillful, responsible thinking that facilitates good judgement because it (1) relies upon criteria, (2) is self-correcting, and (3) is sensitive to context» (1988, p. 39). Ennis defined critical thinking as «reasonable reflective thinking focused on deciding what to believe or do" (1989, p. 4). As it can be seen, authors coincide in the fundamental role of reasoning for critical thinking and in the characteristic of being self-dependent.

For Bailin, Case, Coombs and Daniels (1999a), critical thinking cannot be recognized as a professional skill that a person can develop by repetition and routine. In the same way, Smith (2003) identified two main aspects a critical thinker must have. The first one is to know how to think critically and the second is the attitude of a critical thinker. Many authors define this attitudinal aspect or as Siegel called it — the critical spirit - as necessary; Siegel (2012) defined the critical spirit as the disposition, habit of mind or character trait a critical thinker should have. For Siegel, the cognitive part is not enough because a critical thinker should seek for reasons, evaluate them in a critical manner, and act or judge accordingly. Therefore, it can be concluded that the cognitive aspects of critical thinking are very important; however, it is the attitudinal aspect that will allow a person to actually be a critical thinker. Without the will to question our own beliefs and concepts, and without an open mind, critical thinking will be impossible.

Bailin, Case, Coombs and Daniels (1999b), and Paul and Elder (2001) developed the characteristics of a critical thinker, these included: 1) "responding constructively to reasons and arguments given by others in the context of discussion» (Bailin \& et al, 1999b, p. 289); 2 ) raising central questions and problems; 3 ) being able to formulate them with clarity and precision; 4) gather and analyse relevant information; 5) arrive to well-based conclusions and solutions; 6) test them against relevant criteria and standards; and, 7) demonstrate openmindness, recognize and judge his or her own assumptions, implications and consequences.

Different authors agree that critical thinking is self-directed, self-disciplined, corrected and monitored by oneself. For this, a critical thinker must have two fundamental traits: know-how and attitude. This attitude seeks new ways of improving our thinking and is in itself creative, because it pursues to see things within a new logic, questioning the principles and norms on which it has been built. Actually, this type of reasoning is creative because we design, create, model or produce something new and different, we manage to do it thinking critically about the known, questioning and analysing it from different perspectives.

\section{Critical thinking and innovation}

Paul indicated both creativity and criticality hold mysteries but have an intimate relation. Furthermore, the recognized expert in the topic of critical thinking stated "whenever our thinking excels, it excels because we succeed in designing or engendering, fashioning or originating, creating or producing results and outcomes appropriate to our ends in thinking; 
in a few words, this process has a creative dimension» (1993, p. 22). Paul and Elder (2006) explained that creativity is the mind's generative power and criticality its judiciousness, the systematic thought process involving both aspects provides the logic to both intellectual creation and critical judgment.

Furthermore, Paul and Elder recognized:

Critical and creative thinking are both achievements of thought. Creativity masters a process of making or producing, criticality a process of assessing or judging... When engaged in high-quality thought, the mind must simultaneously produce and assess; and both generate and judge the products it fabricates. In short, sound thinking requires both imagination and intellectual standards $(2008$, p. 4).

If as Paul and Elder (2001) proposed, critical thinking is stripping our preconceptions, social meanings and culture attached to concepts, it can be said it is an exercise of beginning with a clean slate and this is definitely an advantage when asking a person to be creative. Critical thinking asks the individual to literally think outside the box.

\section{Critical thinking as a competency}

The American Management Association (AMA) surveyed 768 managers and executives regarding the importance of what they call the four C's: critical thinking, communication, collaboration and team building; and creativity and innovation as competencies for organizations. Managers recognized the importance of these four competencies for their organizations and identified them as priorities for talent management; $74.65 \%$ of respondents recognized these competencies would only become more important for their companies in the next three to five years. Critical thinking scored (70\%) as the most important competency that would help the organizations grow and innovate (AMA, 2012).

In the same way, many Peruvian universities recognize the importance of critical thinking and include the development of this competency as part of their education plans. However, even though organizations say they need graduates and executives with critical thinking skills, in studies regarding professional competencies such as Manpower's (2015), Universidad del Pacífico (Becerra and La Serna, 2010) and PUCP (Observatorio Laboral, 2013), the competency of critical thinking is not mentioned. Creativity and innovation are consistently identified as professional competencies searched for in Peruvian labour markets. Nonetheless, a basic competency such as critical thinking is not mentioned. An important pending issue is to research if Peruvian managers acknowledge the importance of critical thinking for their companies.

\section{Critical thinking and management education}

Elder and Paul (2001) acknowledged that to develop critical thinking, students must be confronted with their own power to create concepts, see and experience the world. However, Smith declared critical thinking is in many curricula of graduate and undergraduate programs but more as an aspiration than a reality. For Smith, the conclusion is that 
business schools, in spite of their efforts to develop critical thinking, are "not adequate to the challenge of teaching business students how to think effectively» (2003, p. 24). For Behar-Horenstein and Niu (2011) the problem in higher education is that many educational institutions are focused on teaching what to think rather than how to think. It is interesting to highlight that the importance and popularity of critical thinking has not generated, yet, enough research on its development for management education.

Furthermore, Bailin, Case, Coombs and Daniels indicated to teach critical thinking is to orient students. They proposed three ways to achieve this: 1) teach certain necessary concepts, 2) motivate students to make sure their arguments are valid, and 3) teach procedures that will allow the student "to orient himself or herself where certain kinds of reception are sought» (1999a, p. 275). The authors are very clear in proposing there is no magic formula made of steps or stages that will make students think critically (Bailin, Case, Coombs and Daniels, 1999a). Celuch and Slama presented the Foundation for Critical Thinking methods to teach critical thinking: "the course must be reconceptualised not as a set of content areas, but as a method of thinking applicable to solving problems posed within a particular discipline» (1999, p. 135).

Bailin, Case, Coombs and Daniels argued that the main characteristic of critical thinking is the quality of reasoning. Therefore, when developing critical thinking it is necessary to understand the concept of quality of reasoning, and expect students will commit to employing and seeking this specific characteristic. For them:

The knowledge necessary for such understanding includes background knowledge relevant to the context in question, knowledge of the principles and standards of argumentation and inquiry; both in general and in specialized areas, knowledge of critical concepts, and knowledge of relevant strategies and heuristics (1999a, p. 281).

On the other hand, together with the elements presented above there are some attitudes a critical thinker needs to possess such as "open-mindedness, fair-mindedness, the desire for truth, an inquiring attitude and a respect for high-quality products and performances» (Bailin, Case, Coombs and Daniels, 1999a, p. 281). Interestingly, Bailin, Case, Coombs and Daniels (1999b) recognized critical thinking must be related to a purpose such as answering a question, solving a problem, making a decision, taking action or implementing a project.

They proposed three components for teaching critical thinking: the teaching process which needs to help students develop intellectual resources that will help them deal with the situations and tasks mentioned, opportunities for students to engage in situations and tasks that will make them apply their reasoned judgement and assessment; and the need for a motivating environment, where critical thinking is valued, supported and looked for.

\section{Teaching methodologies}

Regarding the teaching process, for Smith an integral program for teaching critical thinking to business students needs to have two main components. First, it needs to "encompass 
general aspects of thinking applicable in all fields of practice» and also, it must address "thinking tasks commonly encountered in organizations» (2003, p. 36). Moreover, Smith (2003) determined that for management education much of the knowledge of thinking required is "task —or function - specific» (2003, p. 36). The author proposed instructional content to develop these thinking skills organized in four clusters:

1. Fundamentals, composed by conceptual foundations, the psychology of thinking, language and thought.

2. Critical thinking with its contents such as inquiry, reasoning, inferential errors and argumentation.

3. Managerial thinking, which is taught through thinking in group, organizational contexts and problem solving.

4. Problem-solving functions, containing problem identification, problem definition, problem analysis, diagnosis, alternative generation, design, decision making and negotiation.

Some teaching methodologies that could facilitate this teaching process are critical pedagogy, active learning and learning communities among others.

\section{Critical pedagogy}

Smith (2003) presented the concept of critical management pedagogy as directly concerned with critical thinking education for management schooling. Reynolds, when defining critical pedagogy, identified two aspects: content which comprises curricula, materials and theories; and a process made up of the structures, procedures, roles and relationships. In the case of content, critical pedagogy proposed the curriculum to include "critical accounts of management theory and practice in various disciplines» (1999a, p. 543). For the process, Reynolds recognized the need to have participative spaces to generate dialogue.

Reynolds (1999b) presented some examples of critical pedagogy with the purpose of developing critical analysis of management topics including the study of language, power, history and culture in different situations and/or organizations. In the same way, Elder and Paul (2001) reflected upon the importance of culture, society and their impact on the conceptualizations people use to describe what they see and confront. For the authors, critical thinking is also about acknowledging that these conceptualizations are not always the truth and questioning them. For Elder and Paul (2001) educating in critical thinking means teaching students how to deepen their reflection, analyse elements such as language and identity to challenge their conceptions and find a new way to see the same elements.

\section{Active learning}

Celuch and Slama (1999) recognized that active learning and problem solving are basic ways of developing critical thinking skills. Bonwell and Eison presented research about this concept applied to higher education and defined it as «anything that involves students in 
doing things and thinking about the things they are doing» (1991, p. 19). Nevertheless, this definition is too general and many different activities could be called active learning. A more aligned concept of critical thinking development is action learning. Action learning's origins are in management education. In 1945 R. W. Revans mentioned the need to develop a staff college for British coal mining industries where «field managers would be encouraged to learn with and from each other using the group review to find solutions to their immediate problems» (Revans, 1982, p. 64). For Revans the primary objective of action learning «is to learn how to ask questions in conditions of risk, rather than to find the answers to questions that have already been precisely defined by others» $(1982$, p. 65).

Due to this, McLaughlin and Thorpe (1993) exposed action learning was founded in the belief that self-development is very important. Therefore, management development is forged by the manager. It is done in a group of pairs with a facilitator, where each member is in a similar position. The group and each invidivual learns how to solve problems and develop management competencies.

When relating this concept to management education, at an undergraduate level at least, there is a need to combine both active and action learning to teach critical thinking through personal experiences but providing some guidance because students still have a long way to go before becoming managers.

\section{Learning communities}

Reynolds presented the Learning Community as a "vehicle for a critical approach in both content and process» (1999a, p. 546). The concept of Learning Community was explained by Reynolds as a participative methodology with the aim of supporting dialogue through its design and educational philosophy.

The structures, procedures and methods, including assessment of the learning community, are, ideally, jointly designed and managed by tutors and students... the most important characteristic, which will ensure a critical learning community... is the availability of analytical perspectives through which students are able to critique the ideas, theories and research they encounter (1997, p. 324).

For Trehan and Rigg «the learning community concept involves increased levels of participation: each individual is recognized, their presence valued, and their contributions produce resources which enhance the collective good» (2007, p. 410).

\section{Opportunities for motivating students}

Regarding the opportunities students must have to develop critical thinking; this compilation seeks to propose courses and activities for management education. The challenge is to implement them and measure their impact.

Paul and Elder proposed six steps to teach critical thinking. The second step is interesting because it proposes eight questions for students to answer and reflect on: 
1. What are the fundamental purposes, goals or agendas of thinking within this discipline?

2. What kinds of questions must be asked or what kinds of problems are solved when thinking within this discipline?

3. What sorts of information or data must be collected or analysed to solve problems within the discipline?

4. What kinds of judgements or evaluations are made by those who interpret and find meaning to data within the discipline?

5. What key assumptions underlie thinking within the discipline and its agenda?

6. What kinds of implications tend to follow from the judgments made and the thinking used within the discipline?

7. What are the key concepts or theories that underlie thinking within the discipline?

8. What is the main point of view one must adopt to think within the discipline?

9. Are there conflicting viewpoints within it? (1999, p. 34).

In addition to this, Browne and Keeley, in their book Asking the Right Questions: A Guide to Critical Thinking, list eleven questions that will help anyone improve their critical thinking skills:

1. What are the issues and the conclusions?

2. What are the reasons?

3. Which words or phrases are ambiguous?

4. What is the value of conflicts and assumptions?

5. What are descriptive assumptions?

6. Are there any fallacies in the reasoning?

7. How good is the evidence?

8. Are there rival causes?

9. Are the statistics deceptive?

10. What significant information is omitted?

11. What reasonable conclusions are possible? $(2007$, p. 13)

It could be interesting to incorporate these questions as part of some fundamental courses in management in order to motivate students to discover and adopt a critical position towards the classic theories and contents studied, and to promote reflection on the subjects. According to Snyder and Snyder «by questioning their thought process, students can begin thinking about their thinking» (2008, p. 95). This is particularly important because it can be easily used in online learning through discussion boards, forums and/or chats.

Smith (2003) presented some management education initiatives developed with the objective of teaching critical thinking, for example through case study, total quality techniques, and writing assignments. Reynolds (1999a) identified some other examples of techniques for teaching critical perspective, such as readings in critical theory and research on topics such as cultural diversity, encouraging students to reflect and analyse their own cultural conceptions in their professional context. In management courses, students could 
be asked to analyse the language, identify cultural patterns and present their position towards information from blogs, articles, and interviews of managers from different organizations, backgrounds and countries.

In the same way, Szenes, Tilakaratna and Maton (2015) analysed a series of activities done by students where critical thinking techniques had to be applied in order to develop and demonstrate the skill. The first activity involved the senior undergraduate class where an essay was written with the purpose of critically reflecting upon a significant event. The instructions for the essay were:

Select a critical incident from your field education experience... analyse the incident through the process of deconstruction and develop new practice theories as a form of reconstruction (Pockett \& Giles, 2008, p. xiv).

The second activity is a reflective journal done by undergraduate business students for a global management course. The objective of this activity was to give students the opportunity to think about intercultural elements (Szenes, Tilakaratna \& Maton, 2015). In this activity, students were also given instructions and a model for analysis to guide their critical reflection. The students were given these questions:

1. Choose one behaviour that you thought was a strength or weakness and identify the "below the surface" value that underpins that behaviour.

2. Having identified the cultural value that you believe underpins your particular strength or weakness; now explain how and from where that cultural value developed using the "core elements of culture».

3. What did this teach you about the way you behave and your expectations of others, when working in multi-national teams?

4. How might you integrate this awareness into future team work, either at university or in the workplace?

Also, Aitken and Deaker presented research on a group of students who used tape recorded journals about consumption for a consumer behaviour paper in their final year marketing course,

[Students] were required to keep a consumption journal. The journal enabled students to select, describe and analyse a range of consumption experiences as a complement to and extension of formal lectures and course readings. Students were required to critique consumer behaviour theory from the experiential perspective of their everyday encounters with consumption (2007, p. 3).

Aitken and Deaker found interesting the following student reactions: 1) «students enjoyed the levels of creativity and personal autonomy that these journals afforded them in mapping out their own particular areas of interest within a range of consumption experiences» (2007, p. 4-5); 2) the process of immediately recording thoughts and feelings and later analysing them more rationally, as well as having more freedom to talk rather than 
to think of how to write, proved a more creative way; 3) students also recognized "the act of talking enabled them to think more clearly and understand things more fully» $(2007$, p. 5); finally, 4) while doing so students were more engaged and involved in their own learning.

Journaling is an activity presented by many authors as important for critical thinking. This proposal of a recorded journal becomes more interesting with the use of technology such as students' smartphones with voice recorders. It can easily be implemented by them.

Athanassiou, McNett and Harvey presented their use of Bloom's Taxonomy as a "scaffolding device to support metacognition. Scaffolding is teaching that provides support to allow the learner to learn for himself or herself» (2003, p. 539). The authors encouraged their students to analyse their coursework against Bloom's Taxonomy and determine the level of learning they were in and the level they could have achieved, motivating critical reflection upon their own learning processes. The results of this study in two groups of students using the taxonomy concluded their critical thinking skills were improved. Those students found the scaffolding technique extremely useful to guide their self-learning (Athanassiou, McNett \& Harvey, 2003, p. 537-543).

By giving students a chance to reflect upon their own learning process, they were given the opportunity to develop their own critical thinking skills. The use of a theory such as Bloom's is adequate for analysing undergraduate management course work.

Dyck, Walker, Starke and Uggerslev presented their results when undergraduate students in an introductory management course were taught two different approaches. The first approach — called the mainstream approach — has a materialist-individualist emphasis on maximizing productivity, profitability, and competitiveness. The other -called the multistream approach - emphasizes balancing multiple forms of well-being for multiple stakeholders (2012, p. 343).

After surveying students, interviewing them and evaluating their case-analysis the authors concluded critical thinking was enhanced «when students viewed the two approaches as ideal types that anchor the extremes of a continuum, and that there was no pure example of (in our study) either a mainstream or a multistream manager» (Dyck \& others, 2012, p. 351). Moreover, students were asked to think about themselves as managers, what kind of managers they wanted to be and why. Dyck and others stated their research «suggests that learning alternative approaches may actually help students to master the conventional approach» (2012, p. 352); by comparing and contrasting, students "gain a much deeper understanding of how to develop an organization's strategy (or how to make a decision, or how to motivate others) if they have two different ways of doing so" (2012, p. 352).

When teaching at an undergraduate level, there are far more opportunities to challenge students with complementing or opposing approaches to many of the management topics. Therefore, this activity could be applied in basic courses such as organizational management or management theory.

Some management undergraduate courses at PUCP's Management School have these types of projects where critical action could be implemented.

2. In 1948, Benjamin S. Bloom developed a taxonomy consisting of a six-level classification to identify student level of achievement in learning, The levels from simple to complex are: knowledge, comprehension, application, analysis, synthesis and evaluation (Athanassiou, McNett \& Harvey, 2003, p. 535). 
Celuch and Slama (1999) shared the design and evaluation of an advertising course based on critical thinking. The objective of the course was to introduce students to the field of advertising by having them think critically about concepts, issues and their application. The authors stressed the importance of developing the course in a different way. Since the first day, they explained the importance of the syllabus because it informed them the scope of the course was different and clarified any questions about it. Furthermore, as part of the course the students were given and asked to sign a Student Understandings Form where the key characteristics of the course were defined. From the first day, "a special effort was made to stress the relevance of critical thinking and the course to students" (Celuch \& Slama, 1999, p. 137), during the first weeks the concept of critical thinking was taught.

Accordingly to the course's objective, the topics were taught through activities which promoted critical thinking. Celuch and Slama designed exercises to create different theories and tools, cross evaluation between peers, research of examples from distinctive theories or perspectives and proposals for accepting or refusing principles or methodologies. All of these activities had an impact on the student's critical thinking skills as they demonstrated progress after the course. Some of the activities that could be replicated are:

- When teaching advertising history, Celuch and Slama motivated their students to think about history in terms of the future. The question they posed was, "Based on advertising's history, which would be the significant issues for advertising in the future and why? What one event is the most significant in advertising's history? Provide your reasoning".

- In the case of segmentation and positioning, Celuch and Slama proposed students to «Choose a product/service that each visual (provided to students) could help advertise. Profile the target audience for the product/service in terms of psychographics. Justify your product/service selection and target audience profile» (1999, p. 138).

- For the topic of advertisement budgeting, the 'thinking episodes' as the authors called them were "Read 'Advertising's Holy Grail'. Summarize the formula's strengths and weaknesses. Given your analysis and your knowledge of ad budgeting, would you adopt the approach? Provide your reasoning".

- Finally, regarding creative strategy the authors asked students to «Develop an ad for smoking prevention that uses unique/unexpected verbal and visual metaphors to convey the message and evaluate one another's ads in terms of unique/unexpected elements» (1999, p. 138).

Although interesting for marketing courses to apply immediately, these activities can also be done in courses such as people management by asking students to analyse the labour market and job offers or selection processes they participate in.

These are some of many other activities teachers can design and implement in management courses. The most important element is the focus and objective of the activity in developing and motivating critical thinking. 


\section{Teachers and Students Resources}

Having recognized the need to develop critical thinking and the importance of the teacher's role in introducing this in management education, many universities have sites dedicated to this competency, with teaching resources and student's guides: The University of Edinburgh $^{3}$, Hong Kong University ${ }^{4}$, University of Manchester ${ }^{5}$, The University of North Carolina at Charlotte ${ }^{6}$, and The University of Texas at Austin 7 . Unfortunately, when doing the same research in Spanish, there were very few university websites sharing content with their teachers and students.

Open University, one of the most important distance learning universities in the world, recognizes critical thinking as a core skill and presents teachers and students with material to help them develop this competency:

Critical thinking is the process of applying reasoned and disciplined thinking to a subject. The higher grades at every level of university study require some critical analysis... As you read your module materials follow these three steps.

Analyse - Examine how key components within your module materials fit together and relate to each other.

Compare - Explore the similarities and differences between the ideas you are reading about. Do some ideas conflict with or complement each other?

Synthesise - Bring together different sources of information to serve an argument or idea you are constructing. Make logical connections between the different sources that help you shape and support your ideas. Are there any inferences you can draw from the material and apply to an assignment question? (OSSS, 2013, $\S 1,3 \& 4)$

On the other hand, TalentLens (2015), a Pearson Education business, presented in the THINK Watson webpage their model called 'Critical Thinking Suite' consisting of:

- Critical Thinking University, an online portal offering eighteen interactive courses with real-world business scenarios. The courses include videos, case studies, quizzes, activities and journal reflections, with online coaching and discussion boards to apply concepts. At the end, the student can unlock

3. For more information, visit: <http://www.ed.ac.uk/schools-departments/institute-academic-development/ postgraduate/taught/learning-resources/critical>.

4. For more information, visit: <http://philosophy.hku.hk/think/critical/>.

5. For more information, visit: <http://www.library.manchester.ac.uk/services-and-support/students/support-foryour-studies/my-learning-essentials/workshops-and-online-resources/?level=3\&level1 Link=3\&level2Links=being $\% 20$ critical>.

6. For more information, visit: <http://teaching.uncc.edu/learning-resources/articles-books/best-practice/criticalthinking >

7. For more information, visit: <http://ctl.utexas.edu/teaching/learning/critical-thinking >. 
a game of solving a robbery through decision making by applying critical thinking. Students have access to a multitude of materials regarding critical thinking to keep developing and exploring the subject.

- Critical Thinking Boot Camp consists of a three-phase program. In the first phase, participants take the Watson-Glaser assessment and ask for feedback from their direct leaders. The second phase is a two-day immersion course into critical thinking for managers. And for the third phase, the instructors follow up with participants and their managers.

- THINK! Now training is a simpler half-day workshop that introduces professionals to critical thinking.

- The Watson-Glaser ${ }^{\mathrm{TM}}$ Critical Thinking Appraisal consists of a development report as a coaching tool and a profile report for selection processes. The Watson-Glaser ${ }^{\mathrm{TM}}$ is presented as "the leading critical thinking test used to assess and develop decision making skills and judgment» (TalentLens). The measuring is based upon the keys to critical thinking in Pearson's model, which are: 1) recognize assumptions, 2) evaluate arguments, and 3) draw conclusions.

- Finally, Pearson's provided an interesting new resource, a critical thinking app to practice the skill called the Think-O-Meter. This is an iPhone app that presents many scenarios that help develop critical thinking by testing your ability to separate facts from assumptions, and arrive to an answer (THINK Watson, 2015).

\section{Conclusion}

Critical thinking is recognized as a foundational competency for innovation and a valuable professional skill. The methodologies, experiences and activities presented above give us a framework and applicable ideas to begin developing critical thinkers who will lead organizations by challenging the actual management practices and innovating into the future. The challenge is ours as educators. 


\section{bibliography}

Aitken, R. \& L. Deaker

2007

«Critical learning and reflective practice:

An exploratory study using tape recorded

journals». Marketing Education Review, 17

(1), pp. 1-5. Retrieved from: <https://doi.org

/10.1080/10528008.2007.11488980>.

\section{American Management}

Association (AMA)

2010

"AMA 2010 critical skills survey». Retrieved

from: <http://www.amanet.org/training/

promotions/AMA-2012-Critical-Skills-

Survey.aspx>.

Athanassiou, N., J. M. Mcnett

\section{\& C. Harvey}

«Critical thinking in the management

classroom: Bloom's taxonomy as a learning tool». Journal of Management Education, 27

(5), pp. 533-555. Retrieved from: <https://

doi.org/10.1177/1052562903252515>

Bailin, S., R. Case, J. R. Coombs

\section{\& L. B. Daniels}

1999a

"Common misconceptions of critical thinking». Journal of Curriculum Studies, 31 (3), pp. 269-283. Retrieved from: <https:// doi.org/10.1080/002202799183124>

\section{Bailin, S., R. Case, J. R. Coombs}

\section{\& L. B. Daniels}

$1999 b$

"Conceptualizing critical thinking".

Journal of Curriculum Studies, 31 (3), pp.

285-302. Retrieved from: <https://doi.

org/10.1080/002202799183133>.

\section{Becerra, A. M. \& La Serna, K.}

Las competencias que demanda el mercado laboral de los profesionales del campo económico-empresarial en la actualidad. Lima, Perú: Centro de Investigación de la Universidad del Pacífico.

\section{Behar-Horenstein, L. S. \& L. Niu}

2011

"Teaching critical thinking skills in higher education: A review of the literature". Journal of College Teaching \& Learning, 8 (2), pp. 25-42. Retrieved from: <https://doi. org/10.19030/tlc.v8i2.3554>

\section{Bonwell, C. C. \& Eison, J. A.}

1991

Active Learning: Creating Excitement in the Classroom. ASHE-ERIC Higher Education Report No. 1. Washington D.C.: The George Washington University.

\section{Browne, M. N. \& Keeley, S. M.}

Asking the right questions: A guide to critical thinking. New Jersey: Pearson Prentice Hall.

\section{Celuch, K. \& M. Slama}

1999

«Teaching critical thinking skills for the 21st century: An advertising principles case study". The Journal of Education for Business, 74 (3), pp. 134-139. Retrieved from: <https://doi. org/10.1080/08832329909601675>.

\section{Dyck, B., K. Walker, F. A. Starke}

\section{\& K. Uggerslev}

2012

«Enhancing critical thinking by teaching two distinct approaches to management». Journal of Education for Business, 87 (6), pp. 343-357.

\section{Ennis, R. H.}

1989

«Critical thinking and subject specificity:

Clarification and needed research».

Educational Researcher, 18 (3), pp.

4-10. Retrieved from: <https://doi.

org/10.1080/08832329909601675> 


\section{bibliography}

\section{Lipman, $M$.}

1988

"Critical Thinking--What Can It Be?»

Educational Leadership, 46 (1), pp. 38-43.

\section{Manpower}

2015

"Talent shortage survey». Retrieved from:

$<$ http://www.manpowergroup.com/wps/

wcm/connect/manpowergroup-en/home/

thought-leadership/research-insights/talent-

shortage-2015>.

\section{Mclaughlin, H. \& R. Thorpe}

1993

«Action learning - A Paradigm in

emergence: the problems facing a

challenge to traditional management

education and development». British

Journal of Management, 4 (1), pp.

19-27. Retrieved from: <https://doi.

org/10.1111/j.1467-8551.1993.tb00158.x>.

\section{Observatorio Laboral PUCP}

2013

Análisis de la demanda laboral de

egresados de pregrado. Lima: PUCP.

Retrieved from: <https://btpucp.pucp.edu.

pe/informes-ml/3046/>

\section{Online Student Support Services (OSSS)}

2013

"Critical reading techniques". Retrieved from: <http://www2.open.ac.uk/students/ skillsforstudy/critical-reading-techniques. php>.

\section{Paul, R.}

1993 "The logic of creative and critical thinking». The American Behavioral Scientist, 37 (1), pp. 21-39

\section{Paul, R. \& L. Elder}

1999

«Critical thinking: Teaching students to seek the logic of things, part II». Journal of Developmental Education, 23 (2), pp. 34-35. Retrieved from: <https://doi.org/10.1 177/0002764293037001004>.

\section{Paul, R. \& L. Elder}

2001

The miniature guide to critical thinking Concepts and tools. California: The Foundation for Critical Thinking.

\section{Paul, R. \& L. Elder}

"Critical thinking: Thinking with concepts". Journal of Developmental Education, 24 (3), pp. 42-43.

\section{Paul, R. \& L. Elder}

"Critical thinking: The nature of critical and creative thought». Journal of Developmental Education. 30 (2), pp. 34-35.

\section{Paul, R. \& L. Elder}

The Thinker's Guide to the nature and functions of Critical \& Creative Thinking. California: Foundation for Critical Thinking Press.

\section{Pockett, R. \& R. Giles (eds.)}

Critical reflection: generating theory from practice: the graduating social work student experience. Sydney, Australia: Darlington Press.

\section{Revans, R.W.}

"What is action learning?» Journal of Management Development, 1 (3), pp. 64-75. Retrieved from: <https://doi. org/10.1108/eb051529>. 


\section{bibliography}

\section{Reynolds, M.}

1997

"Towards a critical management

pedagogy». In J. Burgoyne and M.

Reynolds (eds.), Management Learning:

Integrating perspectives in theory

and practice (pp. 312-328). London:

Sage. Retrieved from: <https://doi. org/10.4135/9781446250488.n19>.

\section{Reynolds, M.}

1999a

Critical reflection and management education: Rehabilitating less hierarchical approaches». Journal of Management

Education, 23 (5), pp. 537-553. Retrieved

from: < https://doi.org/10.1177/1052562999 $\underline{02300506>\text {. }}$

\section{Reynolds, M.}

$1999 b$

"Grasping the nettle: Possibilities

and pitfalls of a critical management

pedagogy». British Journal of

Management, 9, pp. 171-184. Retrieved

from: <https://doi.org/10.1111/1467-

8551.00118>

\section{Szenes, E., N. Tilakaratna \& \\ K. Maton}

2015

«The knowledge practices of

'critical thinking'». In M. Davies

and R. Barnett (eds.), The Palgrave

Handbook of Critical Thinking in

Higher Education. London: Palgrave

Macmillan. Retrieved from: <https://doi.

org/10.1057/9781137378057 34>

\section{Siegel, K.}

2012

"Critical thinking and education.» La

Serena. Retrieved from: <http://www.cel. userena.cl/miel/Web.Admin/documentos/

CURSO1/Chile_Critical_Thinking course 2-12.ppt>.

\section{Smith, G. F.}

"Beyond critical thinking and decision making: Teaching business students how to think». Journal of Management Education, 27 (1), pp. 24-51. Retrieved from: <https:// doi.org/10.1177/1052562902239247>

\section{Snyder, L. G. \& M. J. Snyder}

«Teaching critical thinking and problem solving skills». The Delta Pi Epsilon Journal, 50 (2), pp. 90-99.

\section{TalentLens}

«TalentLens: About us». Retrieved from: $<$ http://talentlens.com/about-us $>$.

\section{Think WATSON}

THINK Watson: Training. Retrieved from: $<$ http://www.thinkwatson.com/training $>$.

\section{Trehan, K. \& C. Rigg}

«Working with experiential learning: a critical perspective in practice». In M. Reynolds and R. Vince (eds.), Handbook of experiential learning and management education. Oxford: Oxford University Press.

Fecha de recepción: 16/03/2016

Fecha de aceptación: 24/01/2017 